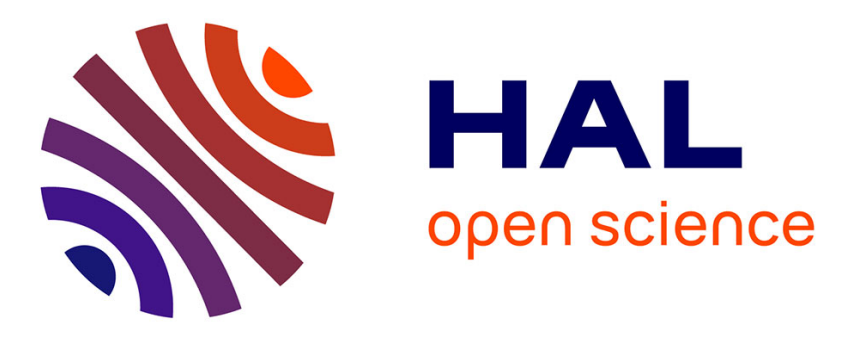

\title{
Enhanced Electrochemical Performance of Ultracentrifugation-Derived nc-Li3VO4/MWCNT Composites for Hybrid Supercapacitors
}

Etsuro Iwama, Nozomi Kawabata, Nagare Nishio, Kazuaki Kisu, Junichi Miyamoto, Wako Naoi, Patrick Rozier, Patrice Simon, Katsuhiko Naoi

\section{To cite this version:}

Etsuro Iwama, Nozomi Kawabata, Nagare Nishio, Kazuaki Kisu, Junichi Miyamoto, et al.. Enhanced Electrochemical Performance of Ultracentrifugation-Derived nc-Li3VO4/MWCNT Composites for Hybrid Supercapacitors. ACS Nano, 2016, vol. 10 ( $\mathrm{n}^{\circ}$ 5), pp. 5398-5404. 10.1021/acsnano.6b01617 . hal-01488468

\section{HAL Id: hal-01488468 https://hal.science/hal-01488468}

Submitted on 13 Mar 2017

HAL is a multi-disciplinary open access archive for the deposit and dissemination of scientific research documents, whether they are published or not. The documents may come from teaching and research institutions in France or abroad, or from public or private research centers.
L'archive ouverte pluridisciplinaire HAL, est destinée au dépôt et à la diffusion de documents scientifiques de niveau recherche, publiés ou non, émanant des établissements d'enseignement et de recherche français ou étrangers, des laboratoires publics ou privés. 


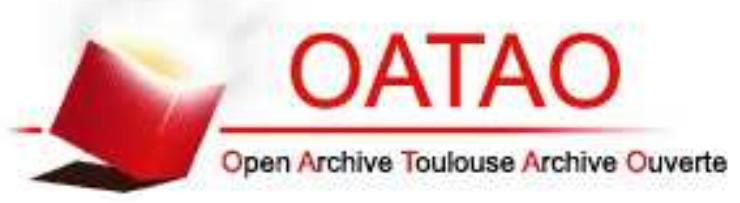

\section{Open Archive TOULOUSE Archive Ouverte (OATAO)}

OATAO is an open access repository that collects the work of Toulouse researchers and makes it freely available over the web where possible.

This is an author-deposited version published in : http://oatao.univ-toulouse.fr/ Eprints ID : 16760

To link to this article : DOI:10.1021/acsnano.6b01617

URL : http://dx.doi.org/10.1021/acsnano.6b01617

To cite this version : Iwama, Etsuro and Kawabata, Nozomi and Nishio, Nagare and Kisu, Kazuaki and Miyamoto, Junichi and Naoi, Wako and Rozier, Patrick and Simon, Patrice and Naoi, Katsuhiko Enhanced Electrochemical Performance of UltracentrifugationDerived nc-Li3VO4/MWCNT Composites for Hybrid Supercapacitors. (2016) ACS Nano, vol. 10 (n 5). pp. 5398-5404. ISSN 1936-0851

Any correspondence concerning this service should be sent to the repository administrator: staff-oatao@ listes-diff.inp-toulouse.fr 


\title{
Enhanced Electrochemical Performance of

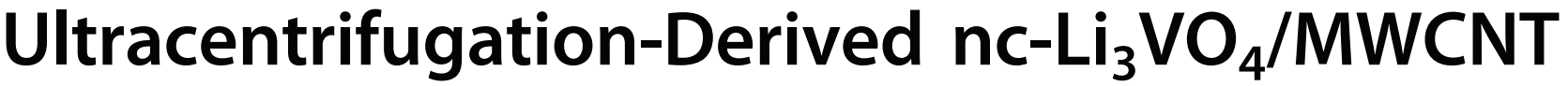 Composites for Hybrid Supercapacitors
}

\author{
Etsuro Iwama, ${ }^{\dagger, \ddagger}$ Nozomi Kawabata, ${ }^{\dagger}$ Nagare Nishio, ${ }^{\dagger}$ Kazuaki Kisu, ${ }^{\dagger, \ddagger}$ Junichi Miyamoto, $^{\dagger, \ddagger, \S}$ \\ Wako Naoi, " Patrick Rozier, ${ }^{\ddagger, \perp, \mathscr{I}}$ Patrice Simon, ${ }^{\ddagger, \perp, \mathscr{I}}$ and Katsuhiko Naoi ${ }^{*}, \neq,, \S, \|$ \\ ${ }^{\dagger}$ Department of Applied Chemistry, ${ }^{\ddagger}$ Global Innovation Research Organization, and ${ }^{\S}$ Advanced Capacitor Research Center, Tokyo \\ University of Agriculture \& Technology, 2-24-16 Naka-cho, Koganei, Tokyo 184-8558, Japan \\ "Division of Art and Innovative Technologies, K\&W Inc., 1-3-16-901 Higashi, Kunitachi, Tokyo 186-0002, Japan \\ ${ }^{\perp}$ CIRIMAT, Université de Toulouse, CNRS, INPT, UPS, 118 route de Narbonne, 31062 Toulouse cedex 9, France \\ ${ }^{\text {II }}$ Réseau sur le Stockage Electrochimique de l'Energie (RS2E), FR CNRS 3459, France
}

S Supporting Information

\begin{abstract}
Nanocrystalline $\mathrm{Li}_{3} \mathrm{VO}_{4}$ dispersed within multiwalled carbon nanotubes (MWCNTs) was prepared using an ultracentrifugation (uc) process and electrochemically characterized in $\mathrm{Li}$-containing electrolyte. When charged and discharged down to $0.1 \mathrm{~V} v \mathrm{Li}$, the material reached $330 \mathrm{mAh} \mathrm{g}^{-1}$ (per composite) at an average voltage of about $1.0 \mathrm{~V} v \mathrm{Li}$, with more than $50 \%$ capacity retention at a high current density of $20 \mathrm{~A} \mathrm{~g} \mathrm{~g}^{-1}$. This current corresponds to a nearly $500 \mathrm{C}$ rate $(7.2 \mathrm{~s})$ for a porous carbon electrode normally used in electric double-layer
\end{abstract} capacitor devices $\left(1 C=40 \mathrm{~mA} \mathrm{~g} \mathrm{~g}^{-1}\right.$ per activated carbon $)$.
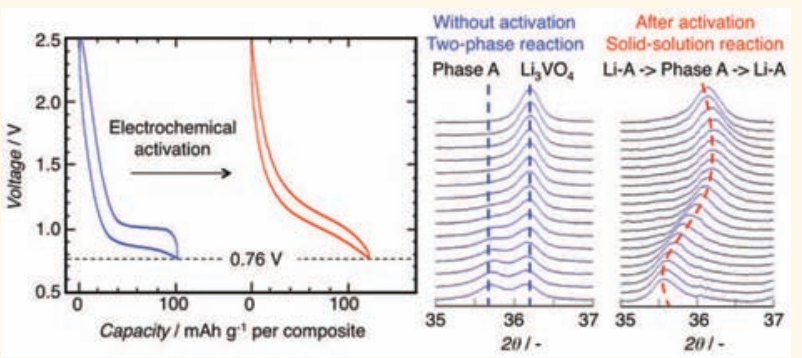
The irreversible structure transformation during the first lithiation, assimilated as an activation process, was elucidated by careful investigation of in operando $\mathrm{X}$-ray diffraction and $\mathrm{X}$-ray absorption fine structure measurements. The activation process switches the reaction mechanism from a slow "two-phase" to a fast "solid-solution" in a limited voltage range (2.5$0.76 \mathrm{~V} v \mathrm{Li}$ ), still keeping the capacity as high as $115 \mathrm{mAh} \mathrm{g}^{-1}$ (per composite). The $\mathrm{uc}_{-} \mathrm{Li}_{3} \mathrm{VO}_{4}$ composite operated in this potential range after the activation process allows fast $\mathrm{Li}^{+}$intercalation/deintercalation with a small voltage hysteresis, leading to higher energy efficiency. It offers a promising alternative to replace high-rate $\mathrm{Li}_{4} \mathrm{Ti}_{5} \mathrm{O}_{12}$ electrodes in hybrid supercapacitor applications.

KEYWORDS: $\mathrm{Li}_{3} \mathrm{VO}_{4}$, ultracentrifugation, hyperdispersion, ultrafast charge storage, initial electrochemical activation, varied energy efficiency

onventional symmetrical carbon supercapacitor or an electric double-layer capacitor (EDLC) is an energy storage device having extremely fast chargingdischarging characteristics, remarkable stability, and long cycle life. ${ }^{1,2}$ Thus, EDLCs are used mainly in applications where instant power is required for a short time (few seconds). The energy density of supercapacitors is low and needs to be enhanced to further expand their applicability. A promising route to fulfill this goal is to design hybrid supercapacitors where an activated carbon electrode is combined with a largecapacity faradic (battery-like) electrode, producing larger energy density than conventional EDLC.

Recently, a new nc- $\mathrm{Li}_{4} \mathrm{Ti}_{5} \mathrm{O}_{12}(\mathrm{LTO}) / \mathrm{LiBF}_{4}(\mathrm{PC}) /$ activated carbon(AC)) hybrid system called a nanohybrid capacitor (NHC) was proposed, with tripled energy density compared to that in EDLC systems. ${ }^{3}$ The NHC is capable of fast charging and discharging (at a rate up to $300 \mathrm{C}$, that is, $12 \mathrm{~s}$ ) for more than 20000 cycles. To further increase the energy density, one way is to replace the high potential LTO electrode $(1.55 \mathrm{~V} v \mathrm{~s}$ $\left.\mathrm{Li} / \mathrm{Li}^{+}\right)$with other negative electrodes operating at lower redox potential.

$\mathrm{Li}_{3} \mathrm{VO}_{4}$ (LVO) has been recently reported to reversibly intercalate up to $2 \mathrm{Li}$ per $\mathrm{LVO}$ at low voltage $(0.1-1.0 \mathrm{~V} v \mathrm{Li})$, leading to a capacity of $394 \mathrm{mAh} \mathrm{g}^{-1} \cdot{ }^{4-8}$ However, LVO exhibits a very low electronic conductivity $\left(<10^{-10} \mathrm{~S} \mathrm{~m}^{-1}\right)$, which is detrimental to achieving high-power performance. It shows as well a large voltage hysteresis between charge and 
discharge (about $\sim 500 \mathrm{mV}$ ) that limits its use as a negative electrode in electrochemical energy storage devices. ${ }^{9-95}$ In addition, the $\mathrm{Li}$ insertion mechanism has not been fully elucidated. ${ }^{16,17}$ Although it is reported that no drastic structural change occurs during the whole reaction because the pristine LVO is recovered after cycling, the change in the electrochemical signature observed between the first and subsequent discharges remains unclear. ${ }^{4,17-20}$ Accordingly, LVO is a lowvoltage anodic material with large capacity, but the rate capabilities need to be improved to be used as a faradic electrode in hybrid supercapacitors. ${ }^{21}$

In this paper, we report the synthesis, structure, and electrochemical characterizations of $\mathrm{LVO} /$ multiwalled carbon nanotube (MWCNT) composite materials prepared using the ultracentrifugation process, ${ }^{3}$ leading to nanosized LVO (10-50 $\mathrm{nm}$ ) hyperdispersed in the MWCNT matrix. MWCNTs were selected because of their compatibility/dispersibility with the raw materials such as vanadium, lithium sources, and polymeric chelating agents in aqueous media. ${ }^{22}$ The capacity of the composite reached $330 \mathrm{mAh} \mathrm{g}{ }^{-1}$ when cycled in a potential range of $2.5 \mathrm{~V}$ down to $0.1 \mathrm{~V}$ vs $\mathrm{Li}$. It shows high power capability, with more than $50 \%$ capacity retention at $20 \mathrm{~A} \mathrm{~g}^{-1}$. This current corresponds to a nearly $50 \mathrm{C}$ rate for LVO $(1 \mathrm{C}=$ $\left.400 \mathrm{~mA} \mathrm{~g}^{-1}\right)$ and $500 \mathrm{C}$ for AC $\left(1 \mathrm{C}=40 \mathrm{~mA} \mathrm{~g}^{-1}\right)$. A careful investigation by means of in operando X-ray diffraction (XRD) and X-ray absorption fine structure (XAFS) measurements revealed the existence of an irreversible structure transformation during the first lithiation reaction, assimilated as an activation process. This activation switches the reaction mechanism from a "two-phase" to a "solid-solution" process in a limited potential window $(2.5 \mathrm{~V}$ down to $0.76 \mathrm{~V} v s \mathrm{Li})$. In this potential range, the $\mathrm{Li}^{+}$intercalation occurs with a small voltage hysteresis, leading to higher energy efficiency and ultrafast $\mathrm{Li}$ insertion kinetics that are required for hybrid supercapacitor applications.

\section{RESULTS AND DISCUSSION}

Structural Characterizations. Comparison of the XRD patterns of the ultracentrifugation (uc)-derived $\mathrm{Li}_{3} \mathrm{VO}_{4}(\mathrm{LVO}) /$ MWCNT composite (Figure 1a) together with the LVO prepared using a conventional synthesis route ${ }^{23}$ (Figure 1b) and the reference LVO (ICDD \# 01-073-6058, Figure 1c) shows that all Bragg peaks can be indexed using the orthorhombic structure of $\mathrm{Li}_{3} \mathrm{VO}_{4}$ with the space group $P n m 2_{1}$; the broad extra peak located close to $2 \theta=28^{\circ}$ corresponds to the 002 peak of MWCNTs. The broadening of the peaks of the uc-prepared sample indicates small particle sizes. The thermogravimetric analysis (TGA) of the composite (Figure 1d) and the pristine MWCNT (Figure 1e) give a composition of $40 \mathrm{wt} \%$ MWCNT and $60 \mathrm{wt} \%$ of LVO for the composite. Also, it shows that all of the ethylene glycol derived polymers were successfully removed from LVO/MWCNT composites during calcination at $300{ }^{\circ} \mathrm{C}$ in air. Transmission electron microscopy (TEM) investigations show that the composite is made of LVO particles clearly identified by the lattice fringes of (010) and (002) planes (Figure 2b), exhibiting a size below $50 \mathrm{~nm}$ (Figure 2a) and homogeneously dispersed, in agreement with previous results on $\mathrm{Li}_{3} \mathrm{~V}_{2}\left(\mathrm{PO}_{4}\right)_{3}$ composites ${ }^{22}$ in the MWCNT matrix. The uc-LVO/MWCNT (60/ 40) shows a specific Brunauer-Emmett-Teller (BET) surface area of $103 \mathrm{~m}^{2} \mathrm{~g}^{-1}$, which is $42 \%$ of the reference ultracentrifuged MWCNT (uc-MWCNT, $246 \mathrm{~m}^{2} \mathrm{~g}^{-1}$ ), as shown in Figure S1. The 58\% decrease in BET surface area may

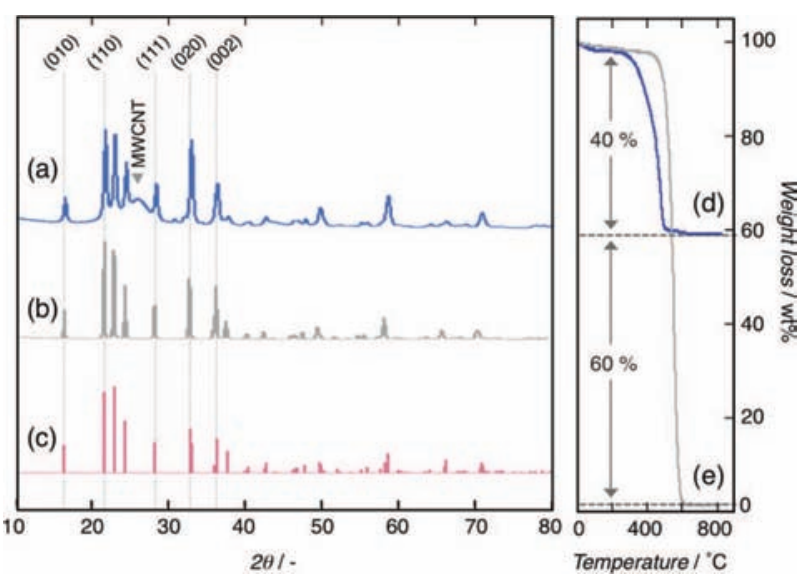

Figure 1. XRD patterns for the (a) uc-derived $\mathrm{Li}_{3} \mathrm{VO}_{4} / \mathrm{MWCNT}$ composite, (b) hydrothermally derived $\mathrm{Li}_{3} \mathrm{VO}_{4}$ bulk, and (c) reference $\mathrm{Li}_{3} \mathrm{VO}_{4}$ pattern ICDD \# 01-073-6058. TGA curves for the

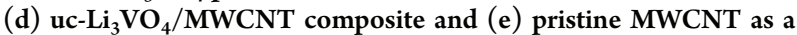
reference. TGA measurements were performed at a sweep rate of $10{ }^{\circ} \mathrm{C} \min ^{-1}$ from ambient temperature to $800{ }^{\circ} \mathrm{C}$ under a synthetic air atmosphere.

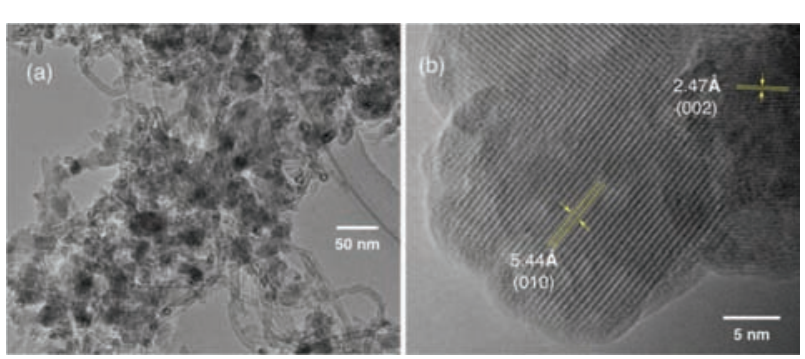

Figure 2. High-resolution TEM images for the uc-derived $\mathrm{Li}_{3} \mathrm{VO}_{4}$ / MWCNT (60/40) composite. (a) Lower-magnification (30 000 $\times)$ image for highly dispersed nanosized $\mathrm{Li}_{3} \mathrm{VO}_{4}$ crystals within the interstices of the MWCNT matrix. (b) Focus on representative $\mathrm{Li}_{3} \mathrm{VO}_{4}$ nanoparticles $(10-15 \mathrm{~nm}$ ) attached on MWCNT surfaces $(300000 \times)$. Clear lattice fringes of $\boldsymbol{d}=\mathbf{0 . 5 4 4}$ and $0.247 \mathrm{~nm}$ appear, corresponding to the (010) and (002) planes of $\mathrm{Li}_{3} \mathrm{VO}_{4}$, respectively.

result in a decrease of the nonfaradic (double-layer) contribution. However, what impacts the capacity as well as the rate performance most is the contribution arising from the composited LVO nanocrystals that have a $60 \mathrm{wt} \%$ ratio in the composites (see the section Electrochemical Characterizations).

Electrochemical Characterizations. The investigation of the electrochemical behavior of the uc-composite at $0.02 \mathrm{~A} \mathrm{~g}^{-1}$ within the full potential window (Figure $3 \mathrm{a}$ ) shows a voltage profile similar to those of LVO samples prepared using conventional routes. $^{23}$ Two shallow plateaus can be seen below and beyond $0.76 \mathrm{~V} v s \mathrm{Li}$ during the discharge, corresponding to a capacity of $2 \mathrm{Li}^{+}$inserted per LVO,, $24-31$ which confirms that the uc treatment does not alter the LVO electrochemical behavior. The investigation of the effect of uc treatment on the rate performances of LVO has been carried out on both charge (delithiation) and discharge (lithiation). The charge curves at different current densities and fixed discharged current $(0.02 \mathrm{~A}$ $\mathrm{g}^{-1}$ ) are shown in Figure 3a. An increase in the current densities up to $10 \mathrm{~A} \mathrm{~g}^{-1}$ leads to a gradual capacity decrease while maintaining the profile shape. For 15 and $20 \mathrm{~A} \mathrm{~g}^{-1}$, the 


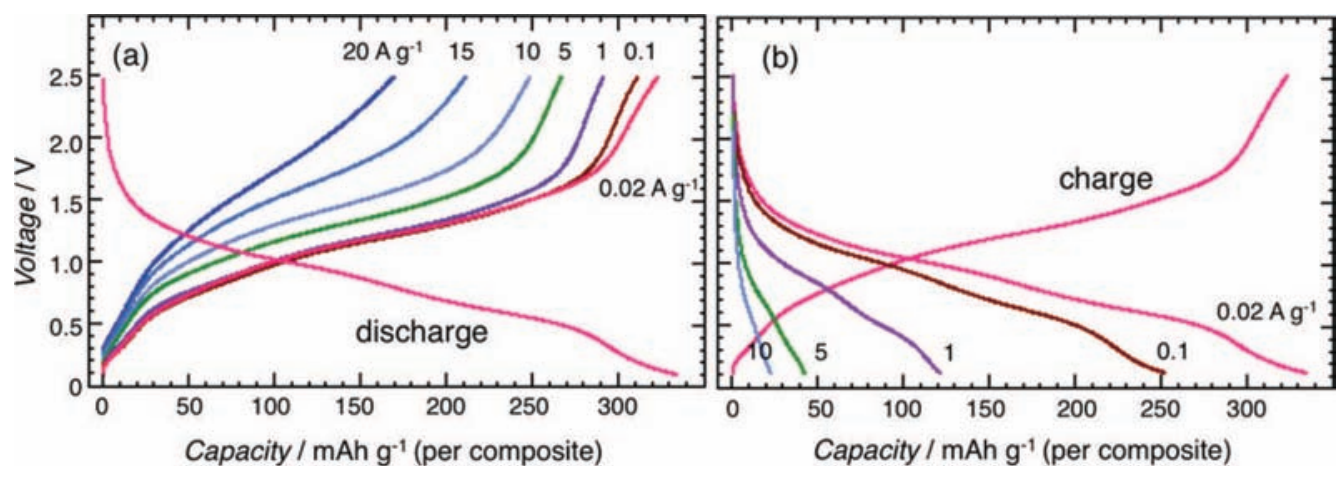

Figure 3. (a) Potential profiles of a half-cell consisting of $\mathrm{Li} / 1 \mathrm{M} \mathrm{LiPF}_{6} \mathrm{EC}+\mathrm{DEC}$ (vol 1:1)/uc-Li $\mathrm{VO}_{4} / \mathrm{MWCNT}$ at different current charge (delithiation) densities of $0.02,0.1,1.0,5.0,10,15$, and $20 \mathrm{~A} \mathrm{~g}^{-1}$ along with the discharge curve at $0.02 \mathrm{~A} \mathrm{~g}^{-1}$. (b) Potential profiles of a halfcell consisting of $\mathrm{Li} / 1 \mathrm{M} \mathrm{LiPF}_{6} \mathrm{EC}+\mathrm{DEC}(\mathrm{vol} 1: 1) / \mathrm{uc}-\mathrm{Li}_{3} \mathrm{VO}_{4} / \mathrm{MWCNT}$ at different discharge (lithiation) current densities of 0.02, 0.1, 1.0, 5.0, and $10 \mathrm{~A} \mathrm{~g}^{-1}$ along with the charge curve at $0.02 \mathrm{~A} \mathrm{~g}^{-1}$.

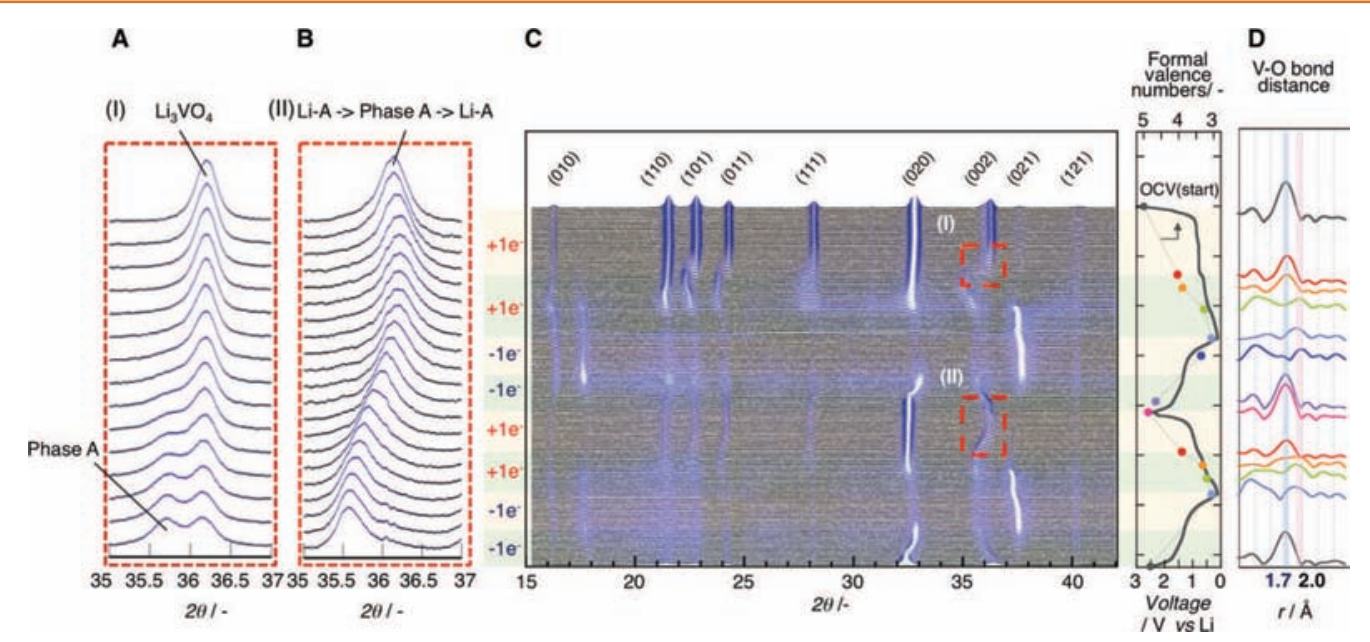

Figure 4. (A,B) Detailed XRD patterns of $2 \theta=35-37^{\circ}$ are separately shown at (I, in panel A) first and (II, panel B) second cycles. In operando XRD (C) and XAFS (D) measurements on a half-cell consisting of $\mathrm{Li} / 1 \mathrm{M} \mathrm{LiPF}_{6}$ in $\mathrm{EC}+\mathrm{DEC}\left(\mathrm{vol}\right.$ 1:1)/uc- $\mathrm{Li}_{3} \mathrm{VO}_{4} / \mathrm{MWCNT}$. Formal valence numbers of vanadium in $\mathrm{Li}_{3} \mathrm{VO}_{4}$ and $\mathrm{V}-\mathrm{O}$ bond distances analyzed by $\mathrm{XAFS}$ are also indicated for the first and second cycles. Voltage profiles during the measurements are shown together with the plots of formal valence numbers (panel $\mathrm{C}$, right).

capacity loss is more pronounced, and a capacity of $157 \mathrm{mAh}$ $\mathrm{g}^{-1}$ corresponding to $50 \%$ of the capacity at a low rate is obtained at $20 \mathrm{~A} \mathrm{~g}^{-1}$. The charge (lithiation) rate characteristics are shown in Figure $3 \mathrm{~b}$. Different from the results obtained during discharge, an important capacity fade appears at low current rates, which is beyond $0.1 \mathrm{~A} \mathrm{~g} \mathrm{~g}^{-1}$. The origin of such a difference is related to the kinetics of the $\mathrm{Li}$ insertiondeinsertion mechanisms of LVO, which is going to be discussed in the following sections.

In Operando XRD and XAFS Studies. In operando XRD and XAFS were used to investigate the Li insertion mechanism into the LVO during galvanostatic cycling at low current density ( $0.02 \mathrm{~A} \mathrm{~g} \mathrm{~g}^{-1}$, corresponding to $0.1 \mathrm{Li}$ exchanged per LVO per hour) to be as close as possible to the steady state. $\mathrm{XRD}$ patterns collected every $0.05 \mathrm{Li}$ exchanged during the first and second cycles are represented in Figure 4C, together with corresponding voltage curve and $\mathrm{V}-\mathrm{O}$ bond distances deduced from X-ray absorption near-edge structure spectra (panel D). The number of electrons $(x)$ used in Figure 4 corresponds to the number of $\mathrm{Li}$ per LVO formula and will be used to characterize the state of charge/discharge in the following. The first discharge starts with almost no visible change in the pristine material structure, in agreement with MWCNT redox activity (Figure S2). This irreversible capacity of the MWCNTs during $\mathrm{Li}$ intercalation explains the difference in the capacity observed between the first and subsequent cycles and will not be considered in the following description. Then, for $0.5 \mathrm{Li}$ inserted per LVO formula, the progressive disappearance of LVO Bragg peaks and the growing of a new set of peaks, very close to that of pristine LVO (see Figure 4A), show the existence of a two-phase mechanism which ends for $x=1$ with the formation of a new phase, named phase $\mathrm{A}$ in the following. Beyond $1 \mathrm{Li}$ intercalated, a progressive shift of the Bragg peaks position indicates a solid-solution mechanism which corresponds to the insertion of $\mathrm{Li}$ in this newly created phase $\mathrm{A}(\mathrm{Li}-$ A phase) and extends to about $1.5 \mathrm{Li}$ intercalated (Figure S3A). Beyond 1.5 Li inserted, a second two-phase mechanism occurs with the progressive disappearance of the Li-A Bragg peaks and the growth of a new set of peaks (see Figure S3B) associated with a new phase named phase B in the following. During further lithiation down to $0.1 \mathrm{~V} v s \mathrm{Li}$, the slight shift of the Bragg peak location seems to indicate a solid-solution reaction mechanism, corresponding to the insertion of extra $\mathrm{Li}$ in phase B (see Figure S3B). A total number of $2 \mathrm{Li}$ per LVO is inserted at $0.1 \mathrm{~V}$ vs Li. 

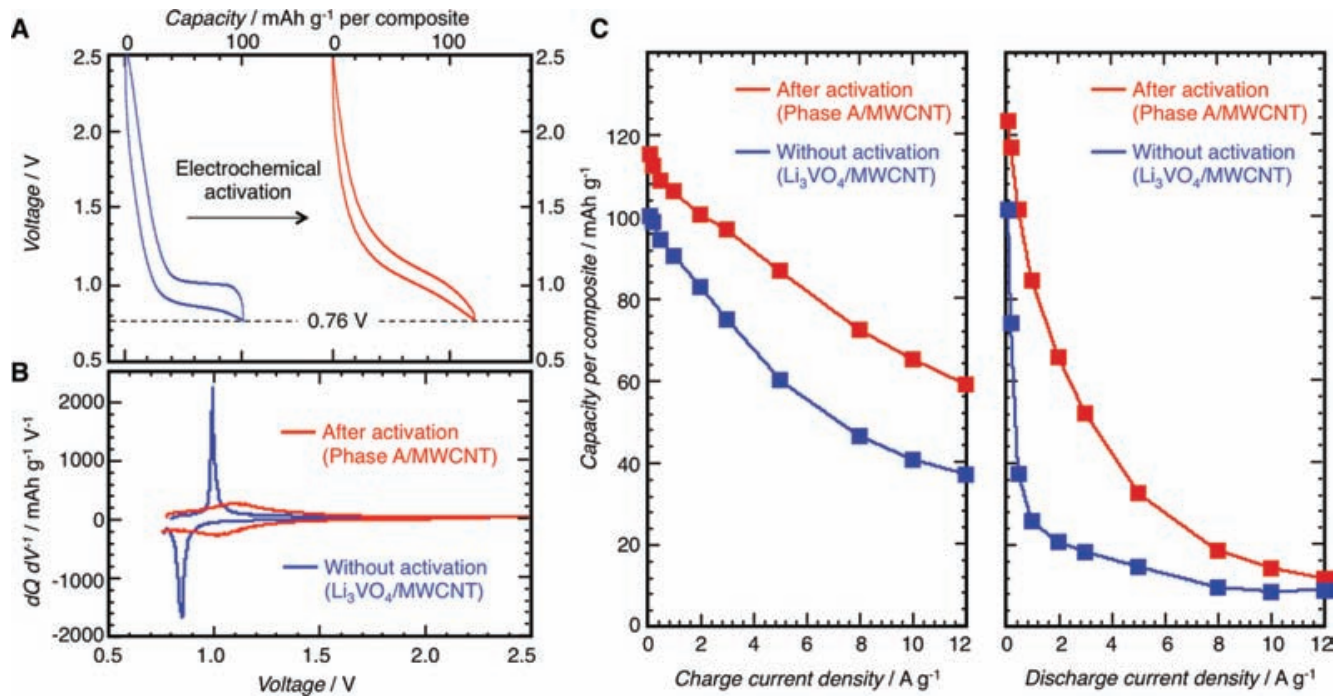

Figure 5. (A) Charge-discharge curves within the limited voltage range from 0.76 to $2.5 \mathrm{~V}$, without and after electrochemical activation. (B) $\mathrm{dQ} / \mathrm{dV}$ plots for $\mathrm{uc}-\mathrm{Li}_{3} \mathrm{VO}_{4} / \mathrm{MWCNT}$ composites without and after activation. (C) Capacity plots with different charge (delithiation) and discharge (lithiation) current densities without and after activation.

During the first charge, the extraction of Li from the lithiated Li-B phase and the two-phase transformation phase B/lithiated phase Li-A are observed (see also Figure S4), indicating the reversibility of the latter processes. Further charge leads to a solid-solution mechanism, which extends up to the full extraction of $\mathrm{Li}$ at $2.5 \mathrm{~V} v \mathrm{Li}$. This clearly shows that, after the first cycle, the fully charged compound (at $2.5 \mathrm{~V} v s \mathrm{Li}$ ) corresponds to a delithiated phase $\mathrm{A}$ and that the system does not convert back to the initial structure of $\mathrm{Li}_{3} \mathrm{VO}_{4}$. This is confirmed by the evolution of the XRD patterns during the second discharge, where a solid-solution process is observed in the $1.5-0.76 \mathrm{~V}$ vs Li voltage range, without any evidence of the two-phase mechanism LVO/phase A (see Figure 4B). Accordingly, in this voltage range, the first discharge corresponds to an activation process with the growing of the phase $\mathrm{A}$, which is the electrochemically active phase and which will never convert back to pristine $\mathrm{Li}_{3} \mathrm{VO}_{4}$. With further increases in the lithiation number (below $0.76 \mathrm{~V} v s \mathrm{Li}$ ), the twophase reaction mechanism between lithiated phase Li-A and phase B is observed. These results clearly differ from previous studies, which consider the existence of a solid-solution mechanism $\mathrm{Li}_{3+x} \mathrm{VO}_{4}$ and a reversible structure change from lithiated $\mathrm{Li}_{3+x} \mathrm{VO}_{4}$ to fully reduced phase $\mathrm{B}$. These different interpretations can be explained by the fact that XRD patterns of the pristine LVO and phase A are similar in relative intensity and close to each other in Bragg angle position. The careful examination of XRD pattern evolution using samples with small changes in Li content allowed us to clearly show during the first discharge the two-phase process and during both first charge and second discharge its irreversibility, as evidenced by the conversion to a solid-solution process. This irreversibility also explains that the difference between the first and second cycle, which was already reported in the literature, ${ }^{4}$ was still subject to debate. Different from the irreversibility between $\mathrm{Li}_{3} \mathrm{VO}_{4}$ and phase $A$, the reversible behavior between phase A and phase B can be seen in both XRD patterns and EXAFS spectra. The reversible shift of $\mathrm{V}-\mathrm{O}$ bond distances between 1.7 and $2.0 \AA$ occurs at $0.5 \mathrm{~V}$ (over $1.5 \mathrm{Li}$ insertion) in the region of the reversible two-phase reaction between phase $\mathrm{A}$ and phase $\mathrm{B}$.
The structure determination of both phases A and B as well as the reaction mechanism path allowing the successive transformations is currently under investigation.

Hysteresis and Morphology Change. In operando XRD study indicates that the $\mathrm{Li}$ insertion in LVO/MWCNT, after the electrochemical activation, involves two new phases, phase $\mathrm{A}$ and phase B. The lithiation of phase A proceeds via a solidsolution (one-phase) mechanism from $2.5 \mathrm{~V}$ down to $0.5 \mathrm{~V} v \mathrm{~s}$ $\mathrm{Li}$ (up to $1.5 \mathrm{Li}$ ), while further lithiation proceeds via a twophase reaction between phase $\mathrm{A}$ and phase $\mathrm{B}$ from $0.5 \mathrm{~V}$ down to $0.1 \mathrm{~V}$ vs $\mathrm{Li}$ (corresponding to $1.5-2 \mathrm{Li}$ inserted per LVO formula). To investigate the effect of such a reaction pathway on the voltage hysteresis during cycling, charge-discharge tests were conducted at different cutoff voltages with and without electrochemical activation. Namely, a pristine sample (LVO/ MWCNT) was charged/discharged within a limited voltage range between 2.5 and $0.76 \mathrm{~V} v \mathrm{Li}$. Another sample (noted as phase A/MWCNT) was first electrochemically activated by cycling between 2.5 and $0.1 \mathrm{~V} v s \mathrm{Li}$ and then cycled within the same voltage range $(2.5$ and $0.76 \mathrm{~V}$ vs $\mathrm{Li})$. The chargedischarge curves are shown in Figure 5A. The pristine LVO/ MWCNT (without activation) shows a clear plateau indicating a two-phase reaction mechanism (Figure 5A, left plot). This demonstrates that as long as the conversion of $\mathrm{Li}_{3} \mathrm{VO}_{4}$ into phase $\mathrm{A}$ is not complete, phase $\mathrm{A}$ is in a metastable state and is converted back to pristine $\mathrm{Li}_{3} \mathrm{VO}_{4}$. This is in perfect agreement with previously reported results showing that the XRD pattern collected ex situ differs from the one collected in operando. ${ }^{17-20,28}$ The full discharge down to $0.1 \mathrm{~V}$ (electrochemical activation) leads to the transformation of pristine $\mathrm{Li}_{3} \mathrm{VO}_{4}$ into phase $A$ and then phase $B$, which prevents the system from being converted back to pristine $\mathrm{Li}_{3} \mathrm{VO}_{4}$. In that case, the sloping electrochemical signature (Figure 5A, right plot) confirms the solid-solution mechanism. Another key feature associated with the electrochemical activation is the important decrease of the voltage hysteresis between discharge (lithiation) and charge (delithiation), indicating that the reversible transformation from A to B via a two-phase mechanism mainly accounts for the hysteresis. Interestingly, the hysteresis became 
even smaller after activation $(<90 \mathrm{mV})$ compared to that without activation $(<150 \mathrm{mV})$, as shown in Figure $5 \mathrm{~B}$.

Finally, the impact of the electrochemical activation on charge (delithiation) and discharge (lithiation) rates has been investigated by cycling the material in different potential ranges. As a general trend, the electrochemical activation improves the charge and discharge kinetics, as can be seen from Figure 5C. A first noticeable effect of the electrochemical activation is the capacity increase (115 and $100 \mathrm{mAh} \mathrm{g}^{-1}$ after and without activation, respectively), which may originate from the improvement in the $\mathrm{Li}$ electrochemical accessibility of the active material after the full insertion/deinsertion of $2 \mathrm{Li}$ per LVO. ${ }^{18-20}$ The capacity retention at both high charge (delithiation) and discharge (lithiation) current density was largely enhanced after the activation. At a rate of $5 \mathrm{~A} \mathrm{~g}^{-1}, 90$ $\mathrm{mAh} \mathrm{g}^{-1}$ of charge capacity and $33 \mathrm{mAh} \mathrm{g}^{-1}$ of discharge capacity were maintained for the sample after activation, while only $55 \mathrm{mAh} \mathrm{g}^{-1}$ (charge) and $17 \mathrm{mAh} \mathrm{g}^{-1}$ (discharge) were kept for the sample without activation. For a high charging rate of $12 \mathrm{~A} \mathrm{~g}^{-1}, 60 \mathrm{mAh} \mathrm{g}^{-1}$ (over $50 \%$ of that at $0.1 \mathrm{~A} \mathrm{~g}^{-1}$ ) was maintained for the sample after the activation, which is higher than that without activation $\left(33 \mathrm{mAh} \mathrm{g}^{-1}\right)$. Here, in the limited voltage range $(2.5-0.76 \mathrm{~V}$ vs $\mathrm{Li})$, we did not see any appreciable growth of the solid electrolyte interface (SEI), leading to the degradation of the power performances. Hence, the effect of the SEI on the rate capability is assumed to be negligible in the limited voltage range we tested. Although improved by the electrochemical activation, the lithiation reaction rate is still limited compared to that of delithiation, thus indicating an electrochemical kinetics limitation intrinsic to the material. However, these results show that, when cycled within a limited potential range after electrochemical activation, uc-LVO/MWCNT can be a promising alternative candidate for replacing LTO as negative electrodes in hybrid supercapacitors.

\section{CONCLUSIONS}

Nanocrystalline $\mathrm{Li}_{3} \mathrm{VO}_{4}$ (LVO), highly dispersed within multiwalled carbon nanotube matrix composites, was prepared by an in situ ultracentrifugation process and characterized as a potential candidate for negative electrodes in hybrid supercapacitors. The uc-LVO/MWCNT capacity composite reached $330 \mathrm{mAh} \mathrm{g}^{-1}$ in Li-containing electrolytes, with $50 \%$ capacity retention up to $20 \mathrm{~A} \mathrm{~g}^{-1}$ (a rate of about 50C). In operando $\mathrm{XRD}$ and XAFS studies revealed the irreversible structure transformation during the first lithiation reaction. This irreversible transformation, assimilated as an electrochemical activation process, switches the reaction mechanism from a "two-phase" $\left(\mathrm{Li}_{3} \mathrm{VO}_{4} /\right.$ phase A) to a fast "solid-solution" (phase $\mathrm{A} / \mathrm{Li}-\mathrm{A})$ in a limited potential range $(2-0.76 \mathrm{~V}$ vs $\mathrm{Li})$. Charge/ discharge tests down to $0.76 \mathrm{~V} v \mathrm{Li}$ show that the origin of the hysteresis mainly comes from the two-phase reaction ( $\mathrm{Li}-\mathrm{A} \rightarrow$ phase B). The capacity retention at both high charge (delithiation) and discharge (lithiation) rates was largely enhanced after the activation. Charge capacity and discharge capacity of 90 and $33 \mathrm{mAh} \mathrm{g}^{-1}$, respectively, were maintained at $5 \mathrm{~A} \mathrm{~g}^{-1}$ for the sample after activation, while only $55 \mathrm{mAh} \mathrm{g}^{-1}$ (charge) and $17 \mathrm{mAh} \mathrm{g}^{-1}$ (discharge) were kept without activation. For a high charging rate of $12 \mathrm{~A} \mathrm{~g}^{-1}, 60 \mathrm{mAh} \mathrm{g}^{-1}$ (over $50 \%$ of that at $0.1 \mathrm{~A} \mathrm{~g}^{-1}$ ) was maintained for the sample after the activation, which is higher than that without activation $\left(33 \mathrm{mAh} \mathrm{g}^{-1}\right)$. Such features make an uc- $\mathrm{Li}_{3} \mathrm{VO}_{4} / \mathrm{MWCNT}$ composite a promising alternative candidate for replacing LTO as the negative electrode in hybrid supercapacitors.

\section{EXPERIMENTAL METHODS}

Materials. $\mathrm{NH}_{4} \mathrm{VO}_{3}$ (99\%, Kanto Chemical Co.), citric acid (99.5\%, Sigma-Aldrich), and ethylene glycol (99\%, Wako Pure Chemical Industries) as well as lithium hydroxide (>98\%, Kishida Chemicals) were used to prepare the composites. AMC (Artificial Micro Carbon) multiwalled carbon nanotubes with a typical diameter of $10-15 \mathrm{~nm}$, a length of $10 \mu \mathrm{m}$, and a specific surface area of $240 \mathrm{~m}^{2}$ $\mathrm{g}^{-1}$ were provided by Ube Industries (Japan).

Synthesis of Nanocrystalline Ultracentrifugation-Derived $\mathrm{Li}_{3} \mathrm{VO}_{4} / \mathrm{MWCNT}$ Composites. First, $0.233 \mathrm{~g}$ of $\mathrm{NH}_{4} \mathrm{VO}_{3}$ (1.00 equiv), $0.383 \mathrm{~g}$ of citric acid ( 1.00 equiv), $0.495 \mathrm{~g}$ of ethylene glycol (4.00 equiv), and $0.143 \mathrm{~g}$ of lithium hydroxide (3.00 equiv) were dissolved in $20 \mathrm{~mL}$ of deionized water. The obtained clear orangecolored solution is characteristic of the presence of $\mathrm{V}^{5+}$ species. Then, $0.181 \mathrm{~g}$ of MWCNT was dispersed under stirring in this solution, which was further ultracentrifuged at $80{ }^{\circ} \mathrm{C}$ for $5 \mathrm{~min}$. The resulting mixture was dried at $130{ }^{\circ} \mathrm{C}$ under vacuum for $12 \mathrm{~h}$ to accelerate the dehydration mechanism, allowing the condensation of ethylene glycol. The obtained powder made of LVO, MWCNTs, and polymer was calcinated at $300{ }^{\circ} \mathrm{C}$ under air for $3 \mathrm{~h}$ to remove the polymer and left to cool to $100{ }^{\circ} \mathrm{C}$. A last flash annealing at $800{ }^{\circ} \mathrm{C}$ under $\mathrm{N}_{2}$ atmosphere $\left(100-800{ }^{\circ} \mathrm{C}\right.$ in $3 \mathrm{~min}$; no dwell; $20 \mathrm{~min}$ cooling to room temperature) was achieved to form the LVO/MWCNT composite. The flash annealing was made to prevent the particle from growing or agglomerating, as previously reported for the preparation of LVP composites. $^{22}$

Physicochemical Characterization of the $\mathrm{Li}_{3} \mathrm{VO}_{4} / \mathrm{MWCNT}$. Phase identification and structure analysis were done by X-ray diffraction (Rigaku SmartLab, $\mathrm{Cu} \mathrm{K} \alpha$ radiation, $\lambda=1.54056$, operating at $45 \mathrm{kV}, 200 \mathrm{~mA}$ ). The XRD patterns were recorded in the $10-80^{\circ}$ $2 \theta$ range with a step rate of $0.1^{\circ} \mathrm{min}^{-1}$. The $\mathrm{Li}_{3} \mathrm{VO}_{4} / \mathrm{MWCNT}$ nanostructure and particle size distribution were characterized using high-resolution transmission electron microscopy (Hitachi model $\mathrm{H} 9500,300 \mathrm{kV})$. TGA was performed under synthetic air $\left(20 \% \mathrm{O}_{2}\right.$, $80 \% \mathrm{~N}_{2}$ ) using a thermogravimetric and differential thermal analyzer (Seiko Instruments, TG/DTA6300). The specific surface area was obtained from $\mathrm{N}_{2}$ adsorption-desorption isotherms (Bel Japan, Inc., BELSORP-max)

Electrochemical Characterizations of $\mathrm{Li}_{3} \mathrm{VO}_{4} / \mathrm{MWCNT}$ Composite Materials. The 2032-type coin cells were assembled using $\mathrm{Li}_{3} \mathrm{VO}_{4} / \mathrm{MWCNT}$ (cathode) and lithium metal (anode) electrodes. Cathodes were prepared by mixing the $\mathrm{Li}_{3} \mathrm{VO}_{4} / \mathrm{MWCNT}$ composite with polyvinylidene difluoride in a $94: 6$ mass ratio in $n$-methyl pyrrolidone; no conducting additives were added to the composite. The mixture was then coated on a $\mathrm{Cu}$ foil (current collector) and dried at $80{ }^{\circ} \mathrm{C}$ under vacuum (ultimate vacuum $=0.67 \mathrm{~Pa}$ ) for $12 \mathrm{~h}$. The electrode was $c a .20 \mu \mathrm{m}$ thick with a weight loading in the range of $1.5-2.0 \mathrm{mg} \mathrm{cm}{ }^{-2}$. The electrolyte was a $1.0 \mathrm{M}$ solution of lithium hexafluorophosphate $\left(\mathrm{LiPF}_{6}\right)$ dissolved in a mixture of ethylene carbonate (EC)/diethyl carbonate (DEC) (50:50 vol ratio) and was supplied from Kishida Chemicals (water content $<50 \mathrm{ppm}$ ). One layer of $25 \mu \mathrm{m}$ thick polypropylene (PP) film (Celgard2400) was used as the separator. Charge-discharge tests were performed between 0.1 and $2.5 \mathrm{~V}$ vs $\mathrm{Li}$ under constant current mode at various current densities ranging from 0.02 to $20 \mathrm{~A} \mathrm{~g}^{-1}$ (HJ-SD8, Hokuto Denko Corp.). To assemble the in operando XRD cell, we used two separators: one layer of a $50 \mu \mathrm{m}$ thick glass fiber separator (Nippon Kodoshi Corp.) and an additional layer of PP separator to avoid any short circuit between uc-LVO/MWCNT and lithium metal electrodes (see Figure S5).

In Operando XAFS Measurements. In operando X-ray adsorption fine structure measurements at the $\mathrm{V} \mathrm{K}$-edges were performed on the composite samples in transmission mode at the beamline BL14B2 of the synchrotron radiation facility Spring-8 (Hyogo, Japan). Laminatetype two-electrode cells (pouch cells) were assembled using a lithium metal foil as the negative electrode and the $\mathrm{Li}_{3} \mathrm{VO}_{4} / \mathrm{MWCNT}$ composite as the positive electrode. Charge-discharge tests were performed within a $0.1-2.5 \mathrm{~V}$ voltage range during the first and second cycles at a rate of $0.02 \mathrm{~A} \mathrm{~g}^{-1}$. XAFS spectra were recorded at various constant potentials after $20 \mathrm{~min}$ at the steady state. The 
obtained XAFS spectra were analyzed using the spectra fitting software REX2000 (Rigaku Corp.) to evaluate the ratio of $\mathrm{V}$ species with different oxidation states, such as $\mathrm{V}^{5+}$ (as prepared $\mathrm{Li}_{3} \mathrm{VO}_{4} / \mathrm{MWCNT}$ ) and $\mathrm{V}^{3+}$ (electrochemically reduced down to $0.1 \mathrm{~V} \mathrm{Li}_{3} \mathrm{VO}_{4} / \mathrm{MWCNT}$ ).

\section{ASSOCIATED CONTENT}

\section{S Supporting Information}

The Supporting Information is available free of charge on the ACS Publications website at DOI: 10.1021/acsnano.6b01617.

$\mathrm{N}_{2}$ adsorption/desorption profiles for uc-LVO/ MWCNT and uc-MWCNT, electrochemical behavior of uc-MWCNTs, in operando XRD and XAFS profiles for uc-LVO/MWCNT composites, and in operando XRD cell configuration (PDF)

\section{AUTHOR INFORMATION}

\section{Corresponding Author}

*E-mail: k-naoi@cc.tuat.ac.jp.

\section{Notes}

The authors declare no competing financial interest.

\section{ACKNOWLEDGMENTS}

This study was supported by the Global Innovation Research Organization in TUAT. The synchrotron radiation experiments were performed at the BL14B2 of SPring- 8 with the approval of the Japan Synchrotron Radiation Research Institute (JASRI) (Proposal No. 2015A1962).

\section{REFERENCES}

(1) Miller, J.; Simon, P. Electrochemical Capacitors for Energy Management. Science 2008, 321, 651-652.

(2) Simon, P.; Gogotsi, Y. Nat. Mater. 2008, 7, 845-854.

(3) Naoi, K.; Ishimoto, S.; Miyamoto, J.; Naoi, W. Second Generation 'Nanohybrid Supercarpactior'. Energy Environ. Sci. 2012, 5, 9363-9373.

(4) Li, H.; Liu, X.; Zhai, T.; Li, D.; Zhou, $\mathrm{H}_{\text {. }} \mathrm{Li}_{3} \mathrm{VO}_{4}$ : A Promising Insertion Anode Material for Lithium-Ion Batteries. Adv. Energy Mater. 2013, 3, 428-432.

(5) Kim, W.-T.; Jeong, Y. U.; Lee, Y. J.; Kim, Y. J.; Song, J. H. Synthesis and Lithium Intercalation Properties of $\mathrm{Li}_{3} \mathrm{VO}_{4}$ as a New Anode Material for Secondary Lithium Batteries. J. Power Sources 2013, 244, 557-560.

(6) Shi, Y.; Wang, J.-Z.; Chou, S.-L.; Wexler, D.; Li, H.-J.; Ozawa, K.; Liu, H.-k.; Wu, Y.-P. Hollow Structured $\mathrm{Li}_{3} \mathrm{VO}_{4}$ Wrapped with Graphene Nanosheets in situ Prepared by a One-Pot Template-Free Method as an Anode for Lithium-Ion Batteries. Nano Lett. 2013, 13, $4715-4720$.

(7) Liang, Z.; Zhao, Y.; Ouyang, L.; Dong, Y.; Kuang, Q.; Lin, X.; Liu, $\mathrm{X}$; Yan, D. Synthesis of Carbon-Coated $\mathrm{Li}_{3} \mathrm{VO}_{4}$ and its High Electrochemical Performance as Anode Material for Lithium-Ion Batteries. J. Power Sources 2014, 252, 244-247.

(8) Shi, Y.; Gao, J.; Abruna, H.-D.; Li, H.-J.; Liu, H.-K.; Wexler, D.; Wang, J.-Z.; Wu, Y. The Mechanism of the One-Step Synthesis of Hollow-Structured $\mathrm{Li}_{3} \mathrm{VO}_{4}$ as an Anode for Lithium-Ion Batteries. Chem. - Eur. J. 2014, 20, 5608-5612.

(9) Chen, L.; Jiang, X.; Wang, N.; Yue, J.; Qian, Y.; Yang, J. SurfaceAmorphous and Oxygen-Deficient $\mathrm{Li}_{3} \mathrm{VO}_{4}-\delta$ as a Promising Anode Material for Lithium-Ion Batteries. Adv. Sci. 2015, 9, 1500090.

(10) Du, C. Q.; Wu, J. W.; Liu, J.; Yang, M.; Tang, Z. Y.; Zhang, X. H. Synthesis of Lithium Vanadium Tetroxide Anode Material via a Fast Sol-Gel Method Based on Spontaneous Chemical Reactions. Electrochim. Acta 2015, 152, 473-479.

(11) Jian, Z.; Zheng, M.; Liang, Y.; Zhang, X.; Gheytani, S.; Lan, Y.; Shi, Y.; Yao, Y. $\mathrm{Li}_{3} \mathrm{VO}_{4}$ Anchored Graphene Nanosheets for Long-Life and High-Rate Lithium-Ion Batteries. Chem. Commun. 2015, 51, 229231.

(12) Zhang, C.; Song, H.; Liu, C.; Liu, Y.; Zhang, C.; Nan, X.; Cao, G. Fast and Reversible Li Ion Insertion in Carbon-Encapsulated $\mathrm{Li}_{3} \mathrm{VO}_{4}$ as Anode for Lithium-Ion Battery. Adv. Funct. Mater. 2015, 25, 3497-3504.

(13) Liu, J.; Lu, P.-J.; Liang, S.; Liu, J.; Wang, W.; Lei, M.; Tang, S.; Yang, Q. Ultrathin $\mathrm{Li}_{3} \mathrm{VO}_{4}$ Nanoribbon/Graphene Sandwich-Like Nanostructures with Ultrahigh Lithium Ion Storage Properties. Nano Energy 2015, 12, 709-724.

(14) Ni, S.; Zhang, J.; Ma, J.; Yang, X.; Zhang, L. $\mathrm{Li}_{3} \mathrm{VO}_{4} / \mathrm{N}$-Doped Graphene with High Capacity and Excellent Cycle Stability as Anode for Lithium Ion Batteries. J. Power Sources 2015, 296, 377-382.

(15) Shao, G.; Gan, L.; Ma, Y.; Li, H.; Zhai, T. Enhancing the Performance of $\mathrm{Li}_{3} \mathrm{VO}_{4}$ by Combining Nanotechnology and Surface Carbon Coating for Lithium Ion Batteries. J. Mater. Chem. A 2015, 3, $11253-11260$

(16) Ni, S.; Zhang, J.; Ma, J.; Yang, X.; Zhang, L.; Li, X.; Zeng, H. Approaching the Theoretical Capacity of $\mathrm{Li}_{3} \mathrm{VO}_{4}$ via Electrochemical Reconstruction. Adv. Mater. Interfaces 2016, 3, 1500340.

(17) Liang, Z.; Lin, Z.; Zhao, Y.; Dong, Y.; Kuang, Q.; Lin, X.; Liu, X.; Yan, D. New Understanding of $\mathrm{Li}_{3} \mathrm{VO}_{4} / \mathrm{C}$ as Potential Anode for Li-Ion Batteries: Preparation, Structure Characterization and Lithium Insertion Mechanism. J. Power Sources 2015, 274, 345-354.

(18) Li, Q.; Wei, Q.; Sheng, J.; Yan, M.; Zhou, L.; Luo, W.; Sun, R.; Mai, Li. Mesoporous $\mathrm{Li}_{3} \mathrm{VO}_{4} / \mathrm{C}$ Submicron-Ellipsoids Supported on Reduced Graphene Oxide as Practical Anode for High- Power Lithium-Ion Batteries. Adv. Sci. 2015, 2, 1500284.

(19) Kim, W.-T.; Min, B. K.; Choi, Y. J.; Jeong, Y. U. Lithium Intercalation and Crystal Chemistry of $\mathrm{Li}_{3} \mathrm{VO}_{4}$ Synthesized by Ultrasonic Nebulization as a New Anode Material for Secondary Lithium Batteries. J. Electrochem. Soc. 2014, 161, A1302-A1305.

(20) Ni, S.; Lv, X.; Ma, J.; Yang, X.; Zhang, L. Electrochemical Characteristics of Lithium Vanadate, $\mathrm{Li}_{3} \mathrm{VO}_{4}$ as a New Sort of Anode Material for Li-Ion Batteries. J. Zhang, J. Ma, X. Yang and L. Zhang. J. Power Sources 2014, 248, 122-129.

(21) Wei, H.-Y.; Tsai, D.-S.; Hsieh, C.-L. A Prelithiated Lithium Vanadate Anode and the Mass Balancing of its Hybrid Capacitor. RSC Adv. 2015, 5, 69176-69183.

(22) Naoi, K.; Kisu, K.; Okita, N.; Shinoda, M.; Muramatsu, M.; Iwama, E.; Naoi, W. Cathode Properties of Nanocrystalline $\mathrm{Li}_{3} \mathrm{~V}_{1.8} \mathrm{Al}_{0.2}\left(\mathrm{PO}_{4}\right)_{3} /$ Multi-Walled Carbon Nanotube Composites for Hybrid Capacitor Prepared via Ultracentrifugation Treatment. Electrochemistry 2015, 83, 249-255.

(23) Li, Q.; Sheng, Z.; Wei, Q.; An, Q.; Wei, X.; Zhang, P.; Mai, L. A unique hollow $\mathrm{Li}_{3} \mathrm{VO}_{4} /$ Carbon Nanotube Composite Anode for High Rate Long-Life Lithium-Ion Batteries. Nanoscale 2014, 6, 1107211077.

(24) Zhao, D.; Cao, M. Constructing Highly Graphitized CarbonWrapped $\mathrm{Li}_{3} \mathrm{VO}_{4}$ Nanoparticles with Hierarchically Porous Structure as a Long Life and High Capacity Anode for Lithium-Ion Batteries. ACS Appl. Mater. Interfaces 2015, 7, 25084-25093.

(25) Li, Q.; Wei, Q.; Wang, Q.; Luo, W.; An, Q.; Xu, Y.; Niu, C.; Tang, C.; Mai, L. Self-Template Synthesis of Hollow Shell-Controlled $\mathrm{Li}_{3} \mathrm{VO}_{4}$ as a High-Performance Anode for Lithium-Ion Batteries. J. Mater. Chem. A 2015, 3, 18839-18842.

(26) Ni, S.; Zhang, J.; Ma, J.; Yang, X.; Zhang, L. Superior Electrochemical Performance of $\mathrm{Li}_{3} \mathrm{VO}_{4} / \mathrm{N}$-Doped $\mathrm{C}$ as an Anode for Li-Ion Batteries. J. Mater. Chem. A 2015, 3, 17951-17955.

(27) Zhang, J.; Ni, S.; Ma, J.; Yang, X.; Zhang, L. High Capacity and Super Long Cycle Life of $\mathrm{Li}_{3} \mathrm{VO}_{4} / \mathrm{N}-\mathrm{C}$ Hybrids as Anode for High Performance Li-Ion Batteries. J. Power Sources 2016, 301, 41-46.

(28) Ni, S.; Lv, X.; Ma, J.; Yang, X.; Zhang, L. The Fabrication of $\mathrm{Li}_{3} \mathrm{VO}_{4} / \mathrm{Ni}$ Composite Material and its Electrochemical Performance as Anode for Li-Ion Battery. Electrochim. Acta 2014, 130, 800-804.

(29) Tartaj, P.; Amarilla, J. M.; Vazquez-Santos, M. B. AerosolAssisted Synthesis of Colloidal Aggregates with Different Morphology: Toward the Electrochemical Optimization of $\mathrm{Li}_{3} \mathrm{VO}_{4}$ Battery Anodes Using Scalable Routes. Chem. Mater. 2016, 28, 986-993. 
(30) Zhang, C.; Liu, C.; Nan, X.; Song, H.; Liu, Y.; Zhang, C.; Cao, G. Hollow-Cuboid $\mathrm{Li}_{3} \mathrm{VO}_{4} / \mathrm{C}$ as High-Performance Anodes for Lithium-Ion Batteries. ACS Appl. Mater. Interfaces 2016, 8, 680-688.

(31) Hu, S.; Song, Y.; Yuan, S.; Liu, H.; Xu, Q.; Wang, Y.; Wang, C.X.; Xia, Y.-Y. A Hierarchical Structure of Carbon-Coated $\mathrm{Li}_{3} \mathrm{VO}_{4}$ Nanoparticles Embedded in Expanded Graphite for High Performance Ion Battery. J. Power Sources 2016, 303, 333-339. 